\title{
Ethidium and Proflavine Binding to a 2',5'-linked RNA Duplex
}

\author{
Eric D. Horowitz and Nicholas V. Hud
}

School of Chemistry and Biochemistry, Parker H. Petit Institute for Bioengineering and Bioscience, Georgia Institute of Technology, Atlanta, GA, 30332-0400

Email: hud@chemistry.gatech.edu

\section{Supporting Information}

\section{Oligonucleotides and extinction coefficients}

\begin{tabular}{|l|c|c|}
\hline Type & Sequence & $\varepsilon_{260}\left(\mathrm{M}^{-1} \mathrm{~cm}^{-1}\right)$ \\
\hline 3',5' RNA & 5'-CCG GCC GCG CGC & $67181 \pm 8 \%$ \\
\hline 3',5' RNA & 5'-GCG CGC GGC CGG & $76819 \pm 6 \%$ \\
\hline 2',5' RNA & 5'-CCG GCC GCG CGC & $63247 \pm 6 \%$ \\
\hline 2',5' RNA & 5'-GCG CGC GGC CGG & $74394 \pm 6 \%$ \\
\hline 3',5' DNA & 5'-CCG GCC GCG CGC & 98700 \\
\hline 3',5' DNA & 5'-GCG CGC GGC CGG & 105700 \\
\hline
\end{tabular}

\section{Materials and Methods}

Oligonucleotides. 3',5' DNA oligonucleotides were purchased from Integrated DNA Technologies (Coralville, IA) and were used as received. 3',5' RNA oligos were purchased from Dharmacon Inc. (Lafayette, CO) and were used as received. 2',5' RNA oligos were synthesized in house on an automated Expedite synthesizer using standard phosphoramidte chemistry (ChemGenes). Following deprotection, oligonucleotides were separated by length on a $20 \%$ denaturing polyacrylamide gel. The band corresponding to the full length product was cut from the gel, extracted from the gel matrix by the crush-and-soak method, loaded onto an anion exchange column, washed with $150 \mathrm{mM} \mathrm{NaCl}$, and eluted with $2.5 \mathrm{M} \mathrm{NaCl}$. The oligonucleotides were then ethanol precipitated, dried, resuspended in $\mathrm{dH}_{2} \mathrm{O}$ and passed over a $1 \mathrm{~m}$ Sephadex G-10 column. Combined fractions containing the purified product were pooled, lyophilized, and resuspended in $\mathrm{dH}_{2} \mathrm{O}$.

Extinction coefficients for 3',5' RNA and 2',5' RNA oligonucleotides were determined by cleavage in $0.3 \mathrm{M} \mathrm{NaOH}$ (Cohn W.E., Methods Enzymol. 1957, 3, 724-743) and comparison to nucleotide monophosphate extinction coefficients (Cavaluzzi, M.J.; Borer, P.N., Nucleic Acids Res. 2004, 32, e13). Extinction coefficient determination was reproducible with less than $8 \%$ variation. Extinction coefficients for DNA oligonucleotides were provided by the manufacturer.

Small Molecules. Ethidium bromide (Fisher) and proflavine hemisulfate (Sigma) were used as received and dissolved in $\mathrm{dH}_{2} \mathrm{O}$. Extinction coefficients used to determine stock solution concentrations were $\varepsilon_{480}=5800 \mathrm{M}^{-1} \mathrm{~cm}^{-1}$ for ethidium and $\varepsilon_{444}=38900 \mathrm{M}^{-1} \mathrm{~cm}^{-1}$ for proflavine.

Fluorescence Data Collection and Analysis. All fluorescence measurements were performed on a Shimadzu RF-5301PC spectrofluorophotometer at $25^{\circ} \mathrm{C}$. Sample solution conditions: $1 \times$ BPE buffer (2 $\mathrm{mM} \mathrm{NaH}_{2} \mathrm{PO}_{4}, 6 \mathrm{mM} \mathrm{Na}_{2} \mathrm{HPO}_{4}, 1 \mathrm{mM} \mathrm{Na} 2$ EDTA) pH 7, $100 \mathrm{mM} \mathrm{NaCl}$, unless stated otherwise. 
Titrations were carried out by making incremental additions of a nucleic acid stock solution to a larger volume solution containing $1 \mu \mathrm{M}$ ethidium or proflavine. The stock nucleic acid solutions also contained the respective small molecule at $1 \mu \mathrm{M}$, in order to avoid dilution of the small molecule over the course of the titration. Ethidium was excited at $510 \mathrm{~nm}$ with a $5 \mathrm{~nm}$ excitation bandwidth and detected with a $5 \mathrm{~nm}$ emission bandwidth. Proflavine fluorescence was excited at $455 \mathrm{~nm}$ with a $1 \mathrm{~nm}$ excitation bandwidth and detected with a $3 \mathrm{~nm}$ emission bandwidth.

Equilibrium constants were derived from fluorescence titration data as described in Qu, X.; Chaires, J. B., Methods Enzymol. 2000, 321, 353-369. Briefly, integrated florescence intensity measurements were fit by the method of least squares using the equations:

$$
\begin{gathered}
K C_{\mathrm{b}}^{2}-C_{\mathrm{b}}\left(K S_{0}+K D_{0}+1\right)+K S_{0} D_{0}=0 \\
F=F^{0}\left(C_{\mathrm{t}}-C_{\mathrm{b}}\right)+F^{\mathrm{b}} C_{\mathrm{b}}
\end{gathered}
$$

where $K$ is the association constant in $\left(\mathrm{M}^{-1}\right), C_{\mathrm{b}}$ is the concentration of bound ligand, $S_{0}$ is the total binding site concentration, $C_{\mathrm{t}}$ is the total concentration of small molecule, $D_{0}$ is the total ligand concentration, $F$ is observed fluorescence at each titration point, $F^{0}$ is fluorescence intensity of the free small molecule, and $F^{\mathrm{b}}$ is the fluorescence of the bound species.

Circular Dichroism and UV-Vis Spectrophotometry. UV-Vis spectra were acquired on a Hewlett Packard 8453 diode array spectrophotometer equipped with an Agilent 89090A Peltier temperature controller. UV melting profiles were produced by monitoring absorbance at $260 \mathrm{~nm}$ while increasing the temperature at a rate of $1^{\circ} \mathrm{C} \mathrm{min}^{-1}$ from 5 to $95^{\circ} \mathrm{C}$. CD spectra were acquired on a JASCO J-810 $\mathrm{CD}$ spectropolarimeter at $25^{\circ} \mathrm{C}$. All CD spectra were baseline subtracted with a separately acquired buffer spectrum. 

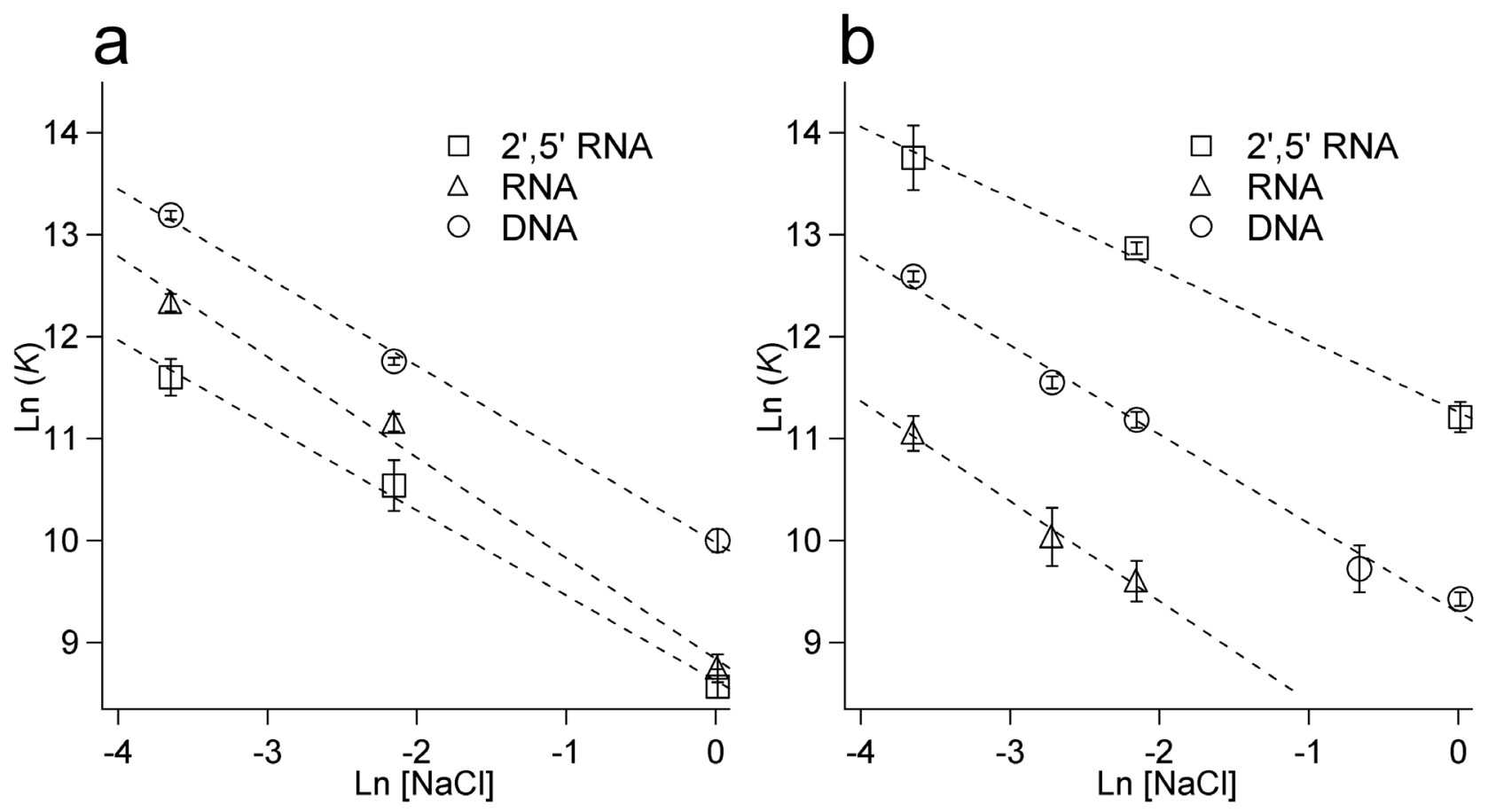

Figure S1. The effect of monovalent cation concentration on proflavine (a) and ethidium (b) association constants for 2',5' RNA, and 3',5' RNA. All association constants were determined by fluorescence titrations, as described above. Measurements were performed in triplicate at $25^{\circ} \mathrm{C}$ in $1 \times$ $\mathrm{BPE}, \mathrm{pH} 7$, with $1 \mu \mathrm{M}$ proflavine or ethidium, respectively. All experiments used the same dodecamer sequence 5'-CCGGCCGCGCGC with its Watson-Crick complement.

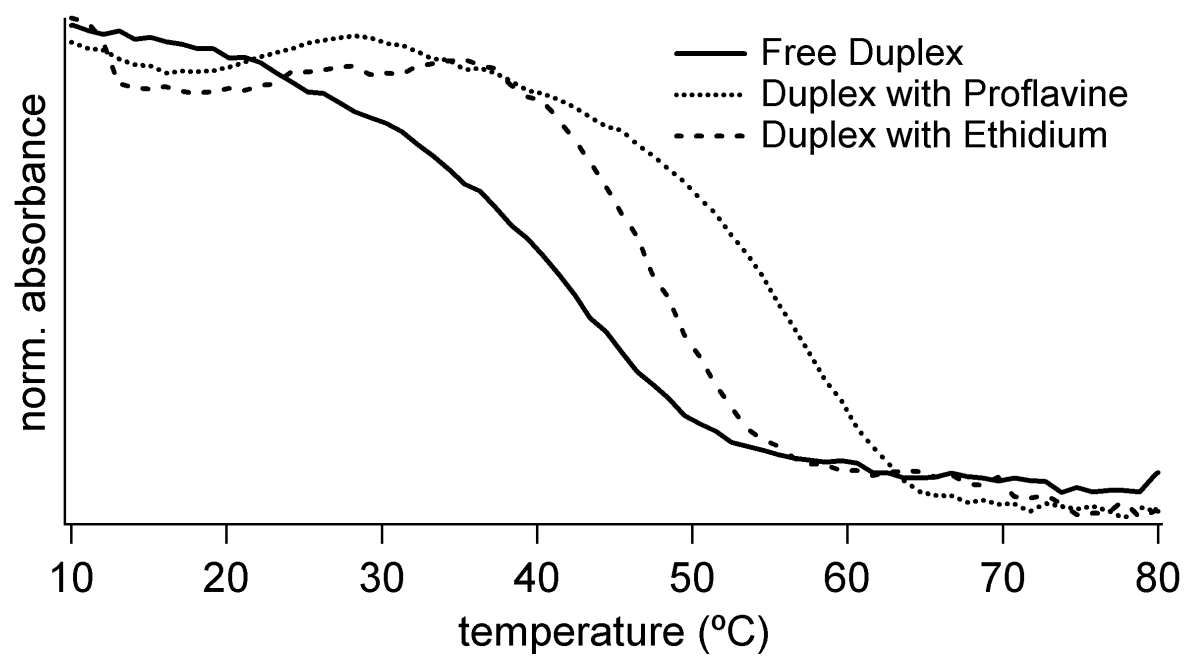

Figure S2. Melting profiles for 2',5'-linked RNA with and without proflavine and ethidium, respectively. Solutions were $40 \mu \mathrm{M}$ nucleic acid in bp, $20 \mu \mathrm{M}$ in small molecule (where applicable), $1 \times \mathrm{BPE}, 100 \mathrm{mM} \mathrm{NaCl}, \mathrm{pH} 7$. All experiments used the same dodecamer sequence (5'CCGGCCGCGCGC). Melting profiles were generated from $260 \mathrm{~nm}$ absorbance and normalized to pre and post-transition baselines. 

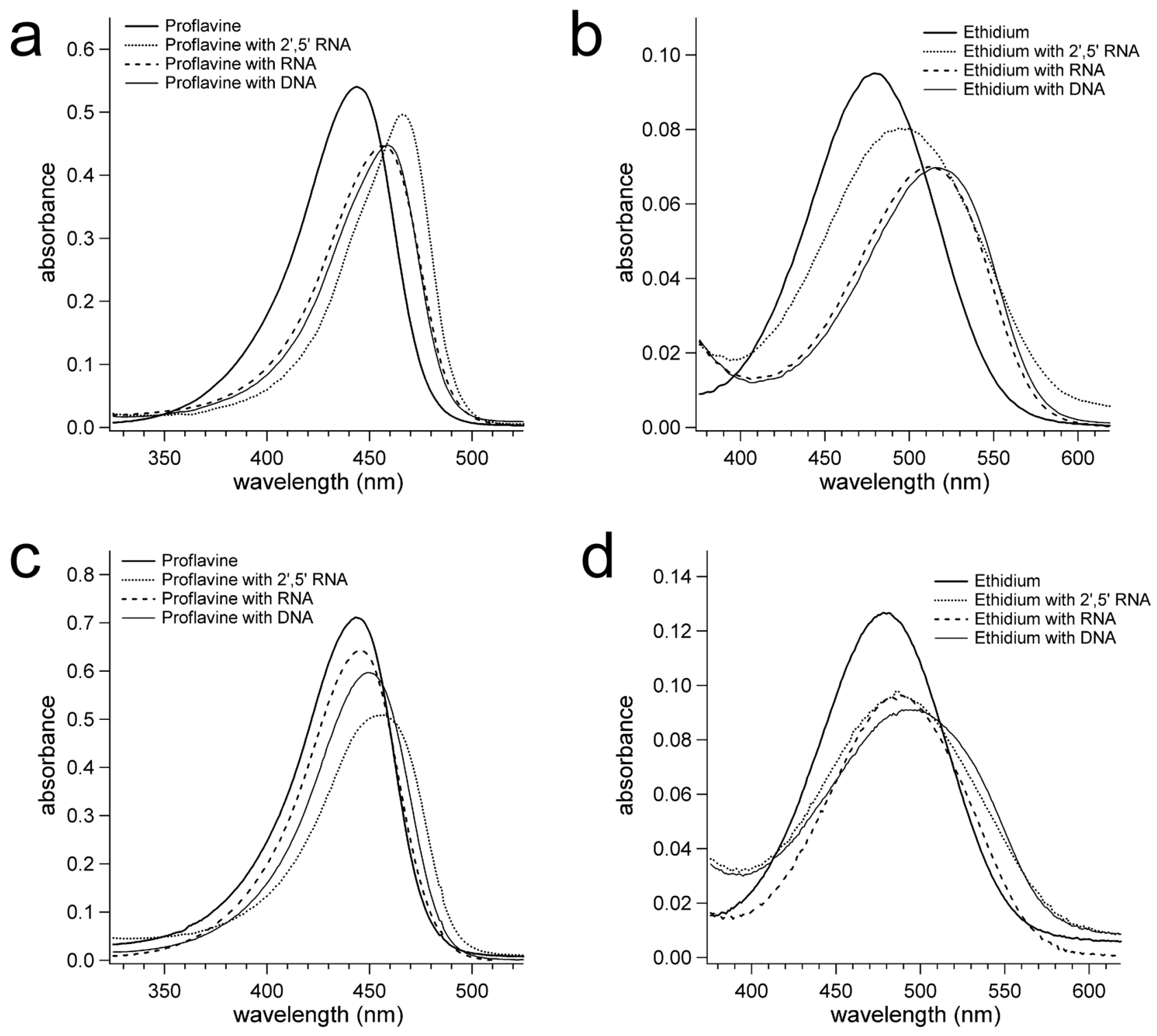

Figure S3. UV-Vis spectra of $16 \mu \mathrm{M}$ (a) proflavine and (b) ethidium free in solution and with 2',5' RNA, RNA and DNA at a concentration $160 \mu \mathrm{M}$ in bp, respectively. UV-Vis spectra of $20 \mu \mathrm{M}$ (c) proflavine and (d) ethidium free in solution and with 2',5' RNA, RNA and DNA at a concentration $40 \mu \mathrm{M}$ in bp, respectively. Spectra were taken at $25^{\circ} \mathrm{C}$ in a $1 \mathrm{~cm}$ path length cell. Buffer conditions $1 \times \mathrm{BPE}, 100 \mathrm{mM} \mathrm{NaCl}, \mathrm{pH}$ 7. Duplex oligonucleotides had the sequence 5'-CCGGCCGCGCGC and its Watson-Crick complement. 

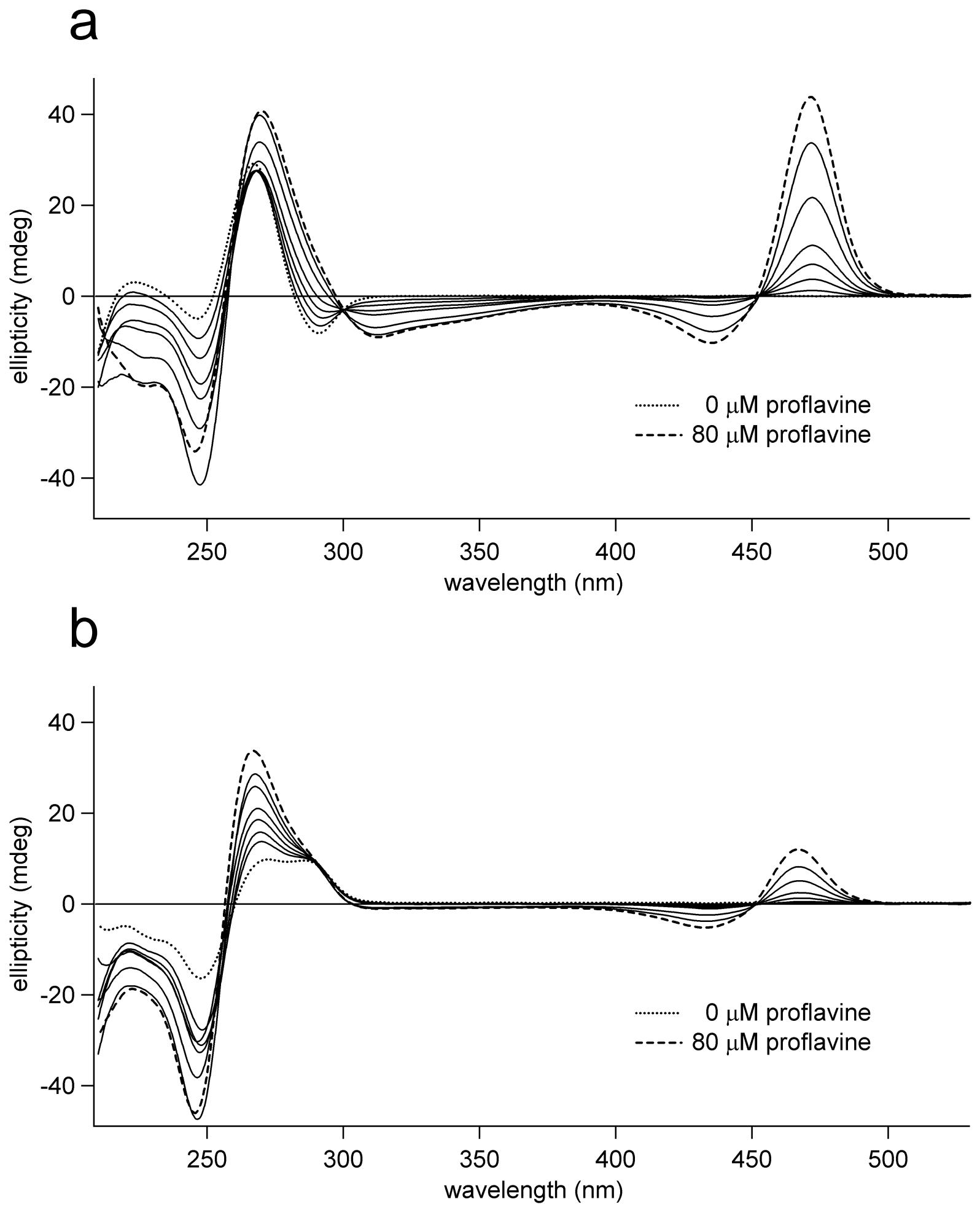

Figure S4. CD spectra of (a) 2',5' RNA and (b) DNA samples, each $160 \mu \mathrm{M}$ in bp, in the presence of proflavine at concentrations of $0,8,16,24,32,48,64$ and $80 \mu \mathrm{M}$. The oligonucleotide sequences were 5'-CCGGCCGCGCGC and its Watson-Crick complement. Spectra were collected at $25^{\circ} \mathrm{C}$ in $1 \times \mathrm{BPE}, 100 \mathrm{mM} \mathrm{NaCl}, \mathrm{pH} 7$, in a $1 \mathrm{~cm}$ path length cell. 